\title{
MDS1 and EVI1 Complex Locus Protein
} EVI1

National Cancer Institute

\section{Source}

National Cancer Institute. MDS1 and EVI1 Complex Locus Protein EVI1. NCI Thesaurus.

Code C17407.

MDS1 and EVI1 complex locus protein EVI1 (1051 aa, 118 kDa) is encoded by the human MECOM gene. This protein is involved in transcriptional regulation. 